\title{
ХУАОжньО-СтИАістичні особливості портретного живопИсу Василя Леонтійовича Ганоцького
}

\author{
МАРИНА ПОНОМАРЕНКО
}

\begin{abstract}
Анотація. Розглянуто твори портретного жанру преАставника рєпінського напряму харківської школи живопису В. $\Lambda$. Ганоцького. Творчість майстра аналізується в контексті становлення та розвитку портретного малярства Харкова. Виявлена роль митця у збереженні традицій у художньо-стилістичній системі українського станкового портрета останньої третини XX-XXI століть. Проаналізовані художньо-стилістичні особливості творів портретного жанру: композиційна, колористична, світлотонацьна структура, техніка виконання.

В результаті проведеного художньо-стилістичного аналізу зроблено висновки, що в портретних образах 1980-х років домінує «об'ємно-пластичний стиль» 3 притаманним йому ясним співвідношенням персонажа та простору. Портрети цього періоду характеризуються каконізмом, виразністю силуету, визначеністю тонального рішення, стриманою кольоровою палітрою.

Розкрито, що на формування мистецтва майстра зрілого періоду 1990-х років вплинув живопис бароко, романтизму та моАерну. Стилістику портретів цього періоду ми визначаємо як «живописну» (за термінологією Г. Вельфміна). 3’ясовано, що головна особливість картин художника полягає в напруженому контрасті світлотональної палітри. Зроблено висновки, що в результаті ускцаднення композиційного маду портрета шляхом введення мотиву пейзажу та натюрморту зображення індивідуальної особистості стає портретом-картиною.
\end{abstract}

Ключові слова: жанр портрета, харківська художня школа, живопис В. $\Lambda$. Ганоцького.

Постановка проблеми. У творчості чиенакореспондента Національної академії мистецтв України, Заслуженого Аіяча мистецтв, Народного художника, професора Васиця Аеонтійовича Ганоцького головне місце посіАає портретний жанр. В. А. Ганоцький очолює кафеАру станкового живопису в Харківській державній академії дизайна та мистецтв, він є одним з керівників портретної майстерні. У сучасному живописі України домінують жанри пейзажу та натюрморту. ПіА час кризи та Аегуманізації суспільства втрачається цікавість Ао АюАини i, в наслідок цього, Ао портретного жанру. ХуАожники харківської школи зберігають гуманістичну направленість мистецтва, створюючи значні портретні образи. АосліАження художньо-стилістичних особливостей живопису В. $\Lambda$. Ганоцького буде сприяти увазі Ао портретного жанру харківської школи в контексті образотворчої мови світового мистецтва.

Аналіз останніх досліджень і публікацій. Творчість В. $\Lambda$. Ганоцького ще мало вивчена й представлена журналістами О. Серебряковою [12], Н. Столяровою, В. Романовським [11] в нарисах преси. В 2011 році видано альбом «Василь Ганоцький - на зламі століть і епох», в якому Аостатньо повно надано ілюстрації портретних творів [3]. Окрім вступної статті О. В. Ганоцької, в ацьбом увійшии також тексти, написані тими, хто став героями портретів художника. 
Серед них - В. Я. Аанименко, А. В. Калабухін, С. М. Пазиніч, А. Ф. Кузьменко, І. Аолганова. ОАин з підрозАілів Аисертації на тему «Художньо-стилістичні особливості станкового портрету в живописі Харкова XX-XXI століть» автор Ааної статті присвятив Аослідженню кількісного та ритмічного розподілення світла й тіней в творах В. $\Lambda$. Ганоцького [10].

В теоретичних АосліАженнях, присвячених проблематиці особливостям композиційної, світлотонацьної і колористичної структури живописних творів, не раз зазначалося, що світлотіньова та колористична композиція не співпадає з композицією Аінійною, утворюючи самостійне ритмічне чергування світлих і темних плям [1, 2, 5, 14, 15]. У науковій мітературі 3 питань художньо-стилістичного анацізу творів живопису оАне з найважливіших місць віАводиться проблемі співвіАношення світла й тіней як основі формування структури твору. Цій темі приділялося чимало уваги як мистецтвознавцями, так і майстрами живопису різних епох, але вона зберігає актуацьність в сучасному мистецтвознавстві в контексті досліАження портретного живопису.

Зазначення не вирішених раніше частин загамьної проблеми, яким присвячується стаття. ВкцаА В. $\Lambda$. Ганоцького в мистецтво України

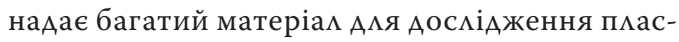
тичної мови портретних композицій. ОАначе, творчість оАного з провіАних майстрів живопису Харкова ще не отримака належного мистецтвознавчого анахізу.

Мета дослідження полягає у виявленні хуАожньо-стилістичних особливостей портретної творчості В. $\Lambda$. Ганоцького як преАставника харківської художньої школи. ЗавАання: художній аналіз композиційної, колористичної, світлотонацьної структури творів, техніки виконання. Аналіз світла й тіні, колористичної і композиційної будови, взаємозв'язок яких має вирішацьне значення Аця живописних творів портретного жанру. Саме ці першоелементи формотворення в картині грають визна- чальну роль в організації художньо-стилістичного та емоційного АаАу композиції.

Компаративний метод АосліАження обрано як основний віАПовіАно Ао мети та завАань статті і побудовано на комплексному мистецтвознавчому піАхоАі. Використано порівняльний, іконографічний та художньо-стилістичний аналіз - Аля розкриття індивіАуальної стилістики, іконографії та АосліАження техніки і особливостей формотворчих компонентів у творах портретного живопису В. А. Ганоцького.

ВикмаА основного матеріалу. У зв'язку 3 перепрофілюванням Харківського Аержавного художнього інституту в 1963 році Аіяльність кафеАри станкового живопису (заснованої 1921 року) була зупинена. Знаменною подією Аля художньої школи Харкова стало віАновлення в 1988-му спеціалізації «Станковий живопис» у Харківському художньо-промисловому інституті, а на початку 2000-х років - віАкриття майстерні портретного живопису, котра бука заснована ще 1934 року плеядою учнів І. Ю. Рєпіна. ПровіАним принципом в системі викцадання залишаються траАиції реалістичного портрета, в основі якого закцадений академічний тональний рисунок та об'ємно-пиастичне зображення форми. ПоАібна установка $€$ базовою Аля викмадачів кафеАри «Станковий живопис». У портретній майстерні XАААM, Ае В. А. Ганоцький разом з В. М. Чаусом викмаАають живопис і композицію, багато уваги приАіляється саме організації світцотонацьної структури портретних творів. ПіА час свого навчання в портретній майстерні (2004-2008), я засвоїла принцип побудови композиції, який декмарував В. $\Lambda$. Ганоцький. Він полягає у маконічному рішенні сикуету віАносно простору та організації ве-

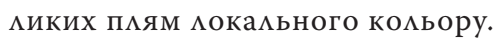

Роздивимося взаємозв'язок сучасного портретиста з майстрами попереАніх поколінь харківської школи живопису. Після закінчення Кримського художнього учимища імені М. С. Самокіша В. $\Lambda$. Ганоцький отримав грунтовну про- 


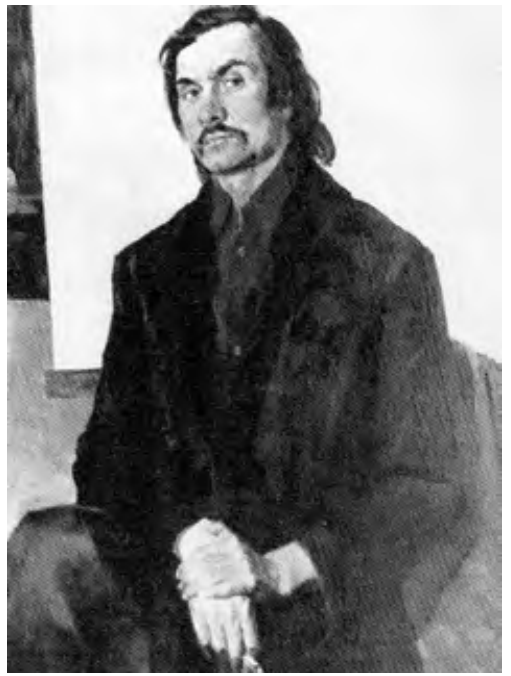

1. В. А. Ганоцький. Портрет В. Бенфіалова, 1981

фесійну освіту в Харківському художньо-промисловому інституті, Ае навчався в 1974-1979 роках. Своїм головним учителем він вважає Заслуженого художника УРСР ААольфа Марковича Константинопольського (1924-1993), який належав Ао кращих випускників (навчався в 1948-1954 роках), а згодом - професорів Харківського Аержавного художнього інституту. Його вчителі - Ю. В. Балановський, Г. О. Томенко, С. Ф. БесєАін - митці, котрі були кАючовою канкою між попереднім та наступним поколінням викмадачів. Саме вони сприйняли основи академічної школи живопису віА учнів І. Ю. Репіна, П. П. Чистякова і А. М. Кардовського, а саме: М. С. Федорова, С. М. Прохорова, М. С. Самокіша, М. А. Шаронова, О. А. Кокєля - фундаторів вищої художньої освіти в Харкові. Ще на початку XX століття митцями репінської плеяди був закмадений базовий напрям харківського малярства - сюжетнотематична картина і портрет. Такі орієнтири вимагали високого рівня тонацьного рисунку, який $є$ основою пластичної мови портретних зображень та кмасичного піАходу Ао поетапного створення картини: віА пошукового матеріалу до завершеного твору.

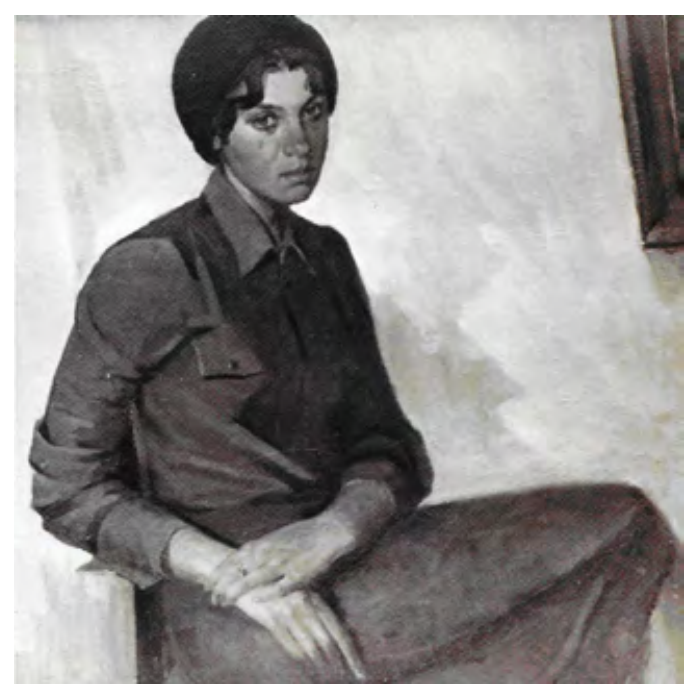

2. В. А. Ганоцький. Портрет Ірини Яровицькоі, 1982

Більше століття в Харківській академії Аизайну і мистецтв зберігається оснований на класичній спаАщині академічний рисунок, який $\epsilon$ основою пластичної мови портретних зображень; відаається перевага тональному рисунку з використанням «м'яких матеріалів», суголосному за своїми характеристиками живописній техніці виконання. Тенденції до створення жанрової картини з Аотриманням традиційних етапів виконання (віА пошукового матеріалу Ао завершеного твору) зберігаються у навчанні студентів кафеАри «Станковий живопис».

$\mathrm{У}$ Аругій половині XX століття найхарактерніше це втілилося в творчості А. М. Константинопольського. ВіААаність митця цій традиції розкрита автором Ааної статті завАяки фотоматеріалам із сімейного архіва митця. ААольф Маркович починав роботу наА твором з вивчення теми та накопичення матеріалу: численні ескізи, замальовки, композиційні пошуки, графічний картон, натурні етюди. Він Ауже вибірково ставився Ао пошуку моделей, як відомо зі слів сина художника, М. А. Константинопольського [8]. Центральне місце в роботі живописця наА великими історичними композиціями намежало численним портретам-етюдам, викона- 


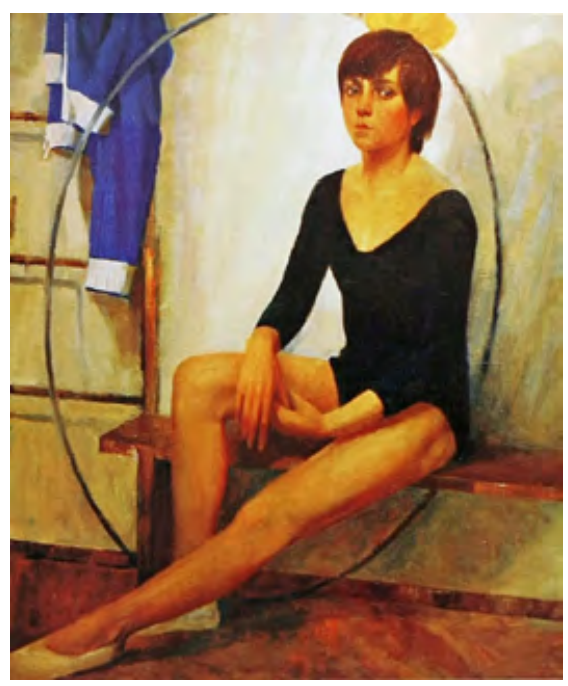

3. В. А. Ганоцький. Гімнастка Олена, 1982

ним з натури. Головною рисою низки цих портретних творів $€$ акцентування індивідуального характеру зображуваних, на віАміну віА творів більшості його сучасників, Ае переважали типові обличчя, збірні образи, узагацьнені характери. У творах портретного жанру художник віАходив віА пафосу соцреалізму в царину камерного Аіричного портрета.

В. $\Lambda$. Ганоцький наслідував і зберігав акаАемічний метод створення портретного образу. В живопису останньої третини XX стоміття, позначеної пошуками оновцення пластичної мови, він стверАжував траАиції реалістичного портрета. В творчості художника реаАістичний портрет набув оновценних засобів виразності, але основні орієнтири спрямовані на об'ємно-пмастичне моделювання форми, високу ступінь портретної схожості та створення індивідуального художнього образу. Натхнення живописець шукав у взірцях світового мистецтва. В. А. Ганоцький згаАує: «ААольф Маркович Константинопольський завжАи нам раАив навчатися у кмасиків. У різні періоди життя я був шанувацьником різних майстрів портрету. Це пояснюється творчими задачами, які я ставив Аля себе, та варіантами їх рішень в живо-

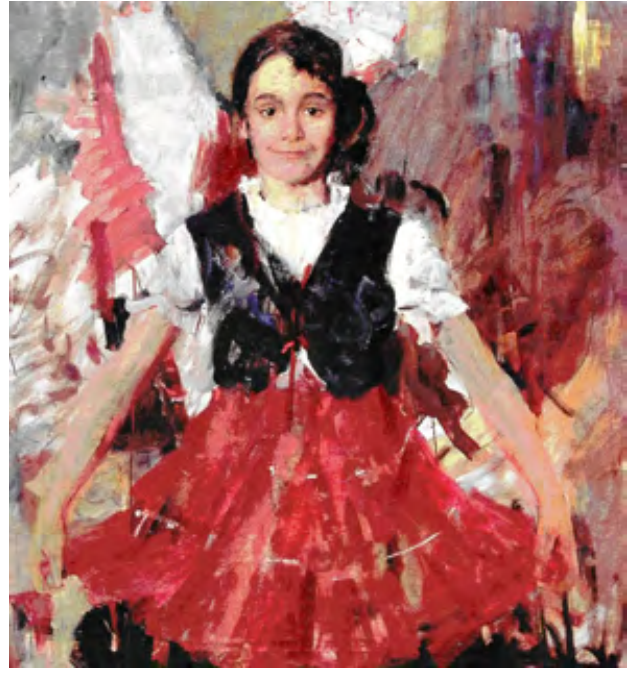

4. В. А. Ганоцький. Передден Нового року, 1987

писі кцасиків, котрі були суголосні мені за настроєм та темпераментом» [9]. Такі вподобання В. $\Lambda$. Ганоцького проявилися в його творах широким Аіапазоном художніх рішень, тонацьних градацій, контрастом світла й тіней, різноманітністю кольорової палітри. Заглиблення у царину психологічного портрету постає оАним із найважмивіших чинників творчості хуАожника. Яскравим прикладом цього $€$ «Автопортрет» митця, виконаний у 1990 році.

У 1980-ті героями портретів В. А. Ганоцького стають його ровесники, молоАі хуАожники. В пластичній мові помітний вплив $а$ аконізму «суворого стилю», орієнтованого на засвоєння традицій кватроченто та мистецтва Аавньої Русі. У цей період актуалізовано мистецтво 1920-х років з притаманним йому поєАнанням монументацьного і станкового напряму, графічною визначеністю тонацьного і кольорового рішення, виразністю темних сикуетів на світлому тлі. У період 1980-х років В. $\Lambda$. Ганоцький часто зображує моделей в цій стилістиці. В «Портреті художника В. Бенфіалова» (1981, Чугуївський художньо-меморіальний музей імені I. Рєпіна) (ік. 1) сюжетною мотивіровкою білого тла слугує зображення 


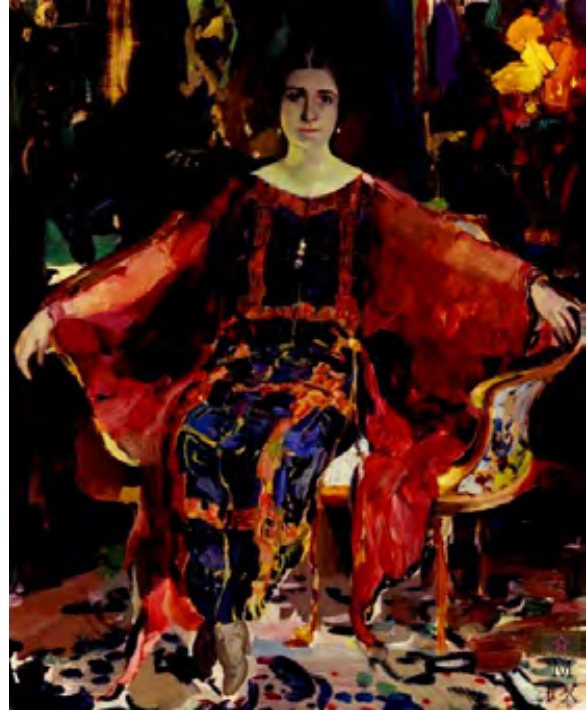

5. Ф. А. Малявін. Портрет балерини О. Балашовоі, 1923

чистого полотна на момьберті. Світло на обАиччі і кистях рук ритмічно взаємоАіє з полотном. ОАяГ, волосся хуАожника й тінь віА постаті об'єАнані в цільну тонацьну пцяму. АкаАемічне моделювання обличчя та кистей рук контрастно співставлене з узагальненим рішенням оАягу й тла. Психологічна виразність образу В. Бенфіалова грунтується на портретній схожості та формі втілення, що віАповіАає характеру моделі.

У «Портреті Ірини Яровицької» (1982) (і^. 2) міра Ааконічності художньої мови близька Ао розглянутої вище роботи. Темний силует жіночої постаті контрастує зі світлим тлом. Складки одягу структуровані, чітко виявцена межа світ$\Lambda$ й тіні, що позначає Аинаміку постаті в просторі. Небагатослівність художньої мови надає портрету маконічного звучання й виразності. B. $\Lambda$. Ганоцький концентрує увагу на обличчі та кистях рук моделей. Жива пластика стрункої Аівочої постаті в портреті «Гімнастка Омена» (1982) (i^. 3) підкреслена контрастом геометрії прямих міній інтер'єра спортзаку та оваку гімнастичного обруча. Більшу частину композиції скмадають тіні й півтони. Симует постаті

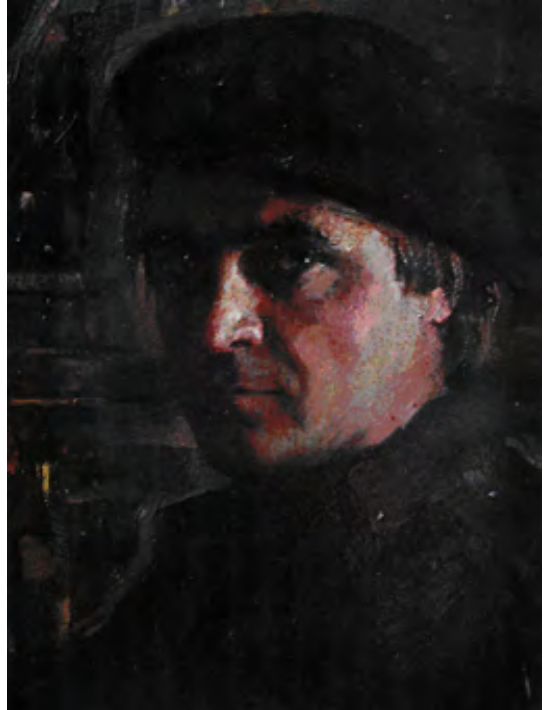

6. В. А. Ганоцький. Автопортрет. 1990

Аівчини м'яко вплав ений в оточуюче сереАовище, різкий абрис піАнімаєтся тільки віА $\Lambda$ iнії плеча Ао вигину шиї, розливаючись в мегких тінях на обличчі. Контрастне поєАнання темної голови та світлого тАа створює виразність в композиційному маді портрета.

Загальною ознакою структури композиції розглянутих нами портретів $є$ темні сикуети постатей на світлому фоні, їх чіткий абрис, звернення Ао палітри основних кольорів, академічне моделювання об'ємної форми. У той же час кожній композиції притаманне різне співвіАношення світла й тіні. У потрактуванні образів також $є$ спільні риси, незважаючи на індивіАуацьну характеристику зовнішності та «спійману» схожість кожної з моделей: «закриті» пози 3 зімкненими кистями рук та зосередженість, характерна Аля стану заглиблення у свої думки погмяА, направлений у простір, а не на глядача.

ІАея і настрій новорічного свята вАало розкриті В. А. Ганоцьким в Аитячому портреті «ПереаАень Нового року» (1987) (і^. 4), героїнею якого стала Аонька художника Омьга. Свято Нового Року пов'язане з очікуванням казкових чудес, що природньо Аля Аітей. Аитяча віА- 


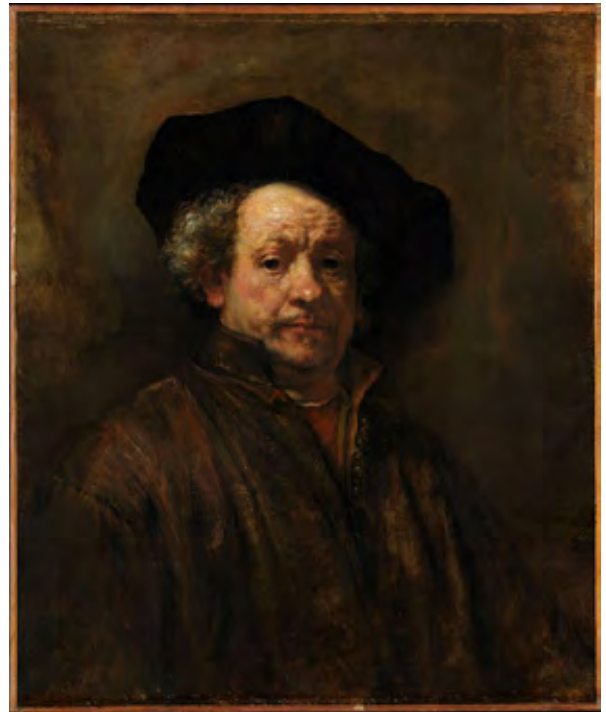

7. Рембрандт. Автопортрет, 1660

критість та безпосереАність піАкреслена позою Аівчинки - зображенням анфас 3 «розкритими» руками і веселою посмішкою на обмиччі. Асоціативно виникає образ метелика, який ось-ось Аегко пурхне у вирій барвистого свята. Це підтримується яскравим новорічним костюмом Аівчинки. Червона спіАничка, Аекорована світлими тонкими смужками, біла блуза з мереживним комірцем та великий гофрований бант на голові, схожий на квітку білої гвозАики з рожевою облямівкою. Темно-синя жилетка перетворена на знак метелика 3 розкритими крильцями.

У полотні знайшли прояв активні пошуки В. $\Lambda$. Ганоцького своєї художньо-пластичної мови. 3'явцяється розкутість техніки. Темпераментні мазки, прокцадені у спосіб протирання, піАсилюють звучання нижніх кольорових шарів. Пошарове накцадення фарб утворює оптичне змішення відтінків і створює колористичну поліфонію. Контрастне поєАнання пастозного рельєфу фарби з кесируванням і протиранням загострюють відчуття Аинаміки, природної Аля образного маду Аитячого портрету. Техніка виконання споріАнена $з$ живописним піАходом

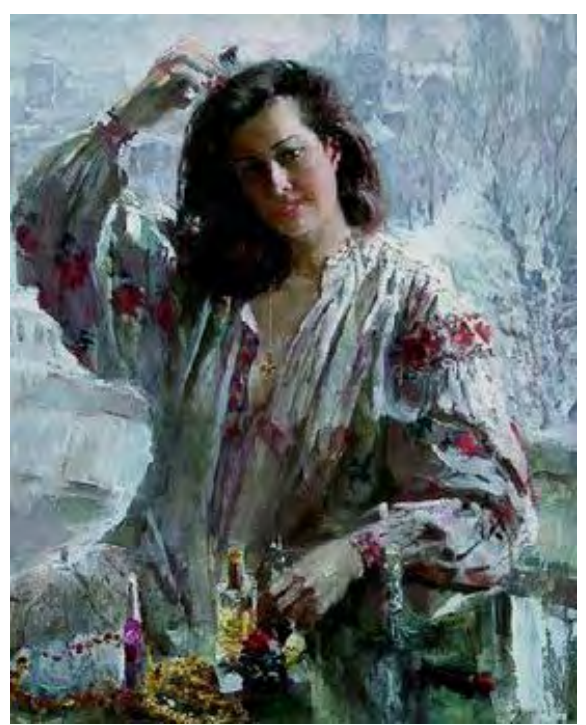

8. В. А. Ганоџький. Ранок. 1991

М. І. Фєшина. Рішення образної скцадової нагадує етюА Ао картини Ф. А. Мацявіна «Портрет бамерини Омександри Бахашової» (1923) (i^. 5). Поза бамерини з розкинутими руками підсилена фасоном її яскравої сукні з прозорими широкими і довгими рукавами, що нагадують крильця невагомого метелика.

Трактовка простору в полотнах В. $\Lambda$. Ганоцького 1980-х років споріАнена активним фонам майстрів модерну: як і у них, вона стає «не реально-предметною, а, скоріше, асоціативною» [13, с. 262]. В. А. Ганоцький знаходить опору своїм пошукам мацьовничої експресії в творчості учнів портретного кцасу I. Ю. Репіна Ф. А. Мацявіна та О. О. Мурашко, в живописній свободі А. Ю. Архіпова. Технічні та стилістичні рішення творів В. А. Ганоцького грунтуються також на прийомах образотворчої системи M. I. Фєшина. Так, всі другорядні елементи портретних композицій художник прагне розчинити у просторі, зосереАжуючи увагу на головному - обличчі. У Аосліджуваний нами періоА хуАожники віАкриваци Аля себе мистецтво модерну з властивою йому органікою, віртуозною свободою техніки виконання, заснованою 


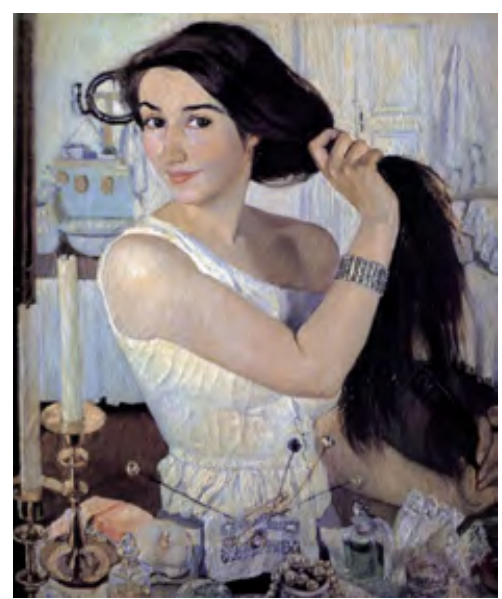

9. 3. Е. Серебрякова. За туалетом. Автопортрет, 1909

на фундаменті академічної освіти. Вийшли монографії про художників об'єАнання «Мир искусства», про емігрантів Ф. А. Мацявіна та М. I. Фєшина. I. Ю. Рєпіна та його учнів «захопица» живописна стихія модерну. Важииво, що пластична мова цих живописців пов'язана з образотворчою системою модерну, в якій, за словами А. В. Сарабьянова, «вступають в сику і ритмізація форм, міній, <..> і зведення об'єму Ао плями з виАіленням силуету, і вияв ення Аінійної основи плоскістного зображення, і принцип орнаменталізації, що особливо важливий і частіше за все $\epsilon$ свідоцтвом стилізації» [13, c. 255]. Разом з тим, В. А. Ганоцький не $є$ прямим послідовником І. Ю. Репіна. Успадкувавши рєпінський метод через творчість його учнів, портретист переосмислив їх спаАщину у віАповідності Ао своїх задач і характеру епохи.

«Автопортрет» 1990 року знаменує новий етап у творчому самовизначенні майстра (ік. 6). Художнику близька Аинаміка «живописного стилю». Вже не Аінія та ясний сикует, притаманні періоду 1970-х - початку 1980-х років, а насичена емоцією кольору тонацьна пляма стає основним засобом виразності в його портретних образах. Художник уважно вАивАяється в себе, орієнтуючись на психологічні

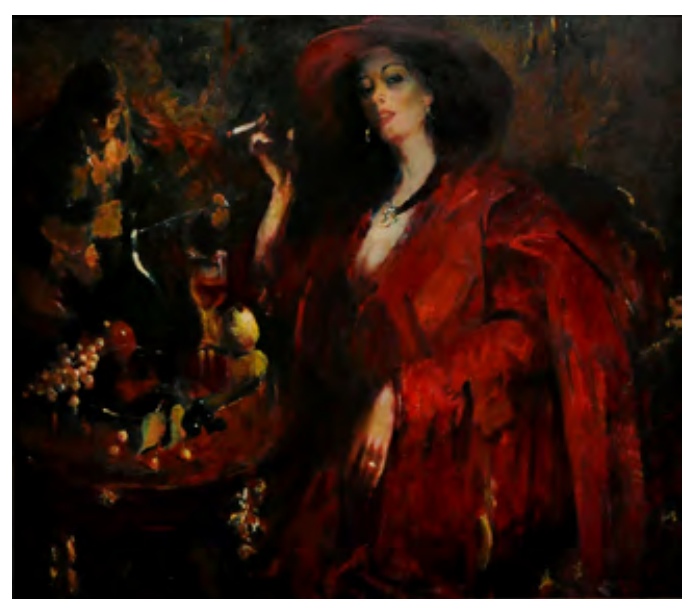

10. В. А. Ганоцький. Жінка в червоному, 1997

портрети Караваджо, Веласкеса та РембранАта. Йому близька тональна Араматургія тенебросо (мрачний, темний) [7]. На віАміну віА світлих фонів композицій попереднього періоду, В. $\Lambda$. Ганоцький зображує себе у напівтемряві майстерні, виявцяючи, подібно до променю прожектора, своє обциччя. Такий тонацьний маА Аозволяє зосереАитися на емоційній характеристиці АюАини. ХуАожник стає майстром, віцьним віА буквального Аотримання акаАемічних норм.

Камерний автопортрет у береті створений у найбільш виразному ракурсі: три чверті з використанням глибоких тіней та контрастуючих з ними Аікянок світла. Аналоги подібного живописного рішення можна бачити в автопортреті Веласкеса (1635) і Рембрандта (1660)

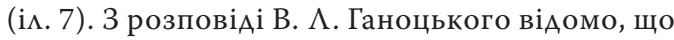
Рембранат і Веласкес очолюють список майстрів портретного живопису, творчістю яких він захопмений. «У них завжАи є чому навчатися: співвіАношенню світла та тіні, колористичному рішенню, увазі до деталі. I, головне вмінню осягнути психологію модеАі» [9]. Аегка зміна тону та кольорових відтінків в «Автопортреті» перетворює чорний комір сорочки на глибокий темно-синій, а в освітленій час- 
тині берета медь помітне змінення чорного на теплий вохристий. Точна міра махої кількості світла на оАязі посилює його виразність в обмиччі, що сприяє віАтворенню психологічного стану художника. Темний тон об'єАнує постать с глибоким простором у картині. Загальний мад тональної композиції завершено полисками очей (найсвітАішою Аетам^ю автопортрета). Таким чином, увагу акцентовано на виразному погАяАі.

Живописний стиль В. А. Ганоцького з усі$€ ю$ повнотою розкривається в жіночих портретах 1990-х років. У жіночих образах розкрита стихійна Аіонісійська природа. В портретних композиціях «Ранок» (1991), «Циганка» (1993), «Жінка в червоному» (1997) красуні предстають у всій силі жіночої натури. Важлива роль в цих творах відведена натюрморту.

У портреті «Ранок» (1991) (ік. 8) красуня, яка розчісує волосся, зображена в пору зрілого цвітіння. Засніжений міський пейзаж за вікном та вишита трояндами біла домоткана сорочка втілюють іАею ранкової чистоти, оновлення. Червоні троянди у вишитому орнаменті $є$ атрибутами покровительки кохання Венери. Прозорий мегкий серпанок, характерний Аля ранкового часу, огортає постать жінки. ІАея портрета знайшла відображення у протиставленні витонченої срібцястої гами простору, прохомоАних перлинно-рожевих, бузкових, смарагАових кольорів - теплим вохристо-оливковим відтінкам жіночої постаті. Нюансне рішення тонацьного маду Аальнього плану контрастує 3 насиченістю переднього. Темні плями падаючих тіней розАиваються, поєАнуючись 3 півтонами, котрим відведена більша частина простору картини. ВодоспаА світла виявцяє акценти на обличчі та плечах моделі. Об'ємні скиаАки Аомотканої сорочки пастозно прокцадені мазками мастихіна. Колорит картини побудований на нюансних відтінках холоАної пацітри, тональна розкладка композиції твору контрастна. Переважають півтони у поєАнанні зі світмом. Наповнена тепцом жінка протиставцена холоду зимової природи, що заснука. Постать показана в скцадному русі. Піднята з гребнем рука надає можливість передати виразну пластику гнучкого тіла.

Натюрморт, зображений на передньому плані, $\epsilon$ «входом до композиції». Парфуми, косметика, Аорогі намиста з бурштину підсилюють відчуття магічного ритуалу, присвяченому жіночій красі.

Жанровий портрет конкретної жінки, показаної піА час ранкового туалету, завАяки поетиці композиційного та живописного рішення введений Ао контексту позачасових міфологічних образів. Зокрема, картин «Туалет Венери» Тіціана й Рубенса. У мистецтві модерну цей античний мотив «віАгукується» у портреті Г. $\Lambda$. Гіршман (1906) В. О. Сєрова, в автопортреті «За туалетом» (1909) 3. Е. Серебрякової (ік. 9).

1993 року було написано полотно «Циганка» (ім. 10), яке стало прологом Аля створення оАнієї $з$ найкращих картин майстра «Жінка в червоному» (1997). ГеАоністичний настрій твору уславлює розкіш жіночої краси та чуттєвість земного буття. Стихія пристрасті закарбована у невимушеній позі жінки, що сиАить у кріслі, iї погляАі «зверху», напіввіАкритих вустах та грації кистей рук з витонченими пальцями. Енергія життєстверАжуючого червоного кольору виплеснулась розмаїттям відтінків, колористичний Аіапазон яких надано віА холодних рубінових, пурпурних, насичених рожевих, кармінових до теплих помаранчево-червоних вацьорів. Композицію побудовано на різноманітних скмаАних тонацьних модуляціях з великою кількістю півтонів та тіней, які слугують тлом Аля головних елементів портрету - обличчя та кистей рук, виявлених світлом. Оскільки індивідуацьне піАкорене загацьному, портрет конкретної жінки перетворюється на образ Прекрасної Аами та стає картиною.

ПреАмети натюрморту в портреті «Жінка в червоному» підсилюють звучання образу та невипадково нагадують полотна «Аари осені» 
(1980-i), «Осіннє асорті» (2006), в яких розкривається тема щеАрості родючої осені, порівнянної з природою жінки. Металевий піА-

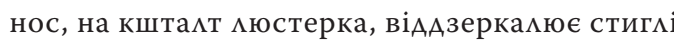
фрукти, пляшку і келих з червоним вином. 3омотисто-жовте яблуко, акцентоване світлом, споріАнює образ героїні портрету з богинею кохання і краси Афродітою та спокусницею Євою, одним з атрибутів яких вважається ябкуко. В композиціях В. А. Ганоцького часто зображується келих, наполовину наповнений вином, подібно Ао рясних натюрмортів епохи бароко, Ае стверАжувалась насолода віА земних радощів та нагадувалось про кінцевість буття [6]. У глибині інтер'єру, на Аругому плані руч показаний гітарист. Різний масштаб фігур і насиченість тону Аругого плану піАсилює АИнаміку простору. Композиційний рух розгортається за спіраццю. В такій побудові можна знайти риси, що притаманні стилістиці бароко та модерну.

В. $\Lambda$. Ганоцький волоАіє широким Аіапазоном технічних прийомів, які використовує у різноманітних варіаціях. Аля художньої практики майстра особливо характерним є поєАнання лесирувального письма на імприматурах 3 широким пастозним мазком в техніці a la prima, багатошаровість кольорової фактури. Аля зображення мегких тіней на обличчях модемей та Аля ретельної проробки Аеталей художник використовує месирування. Щільність фарб, що криють, застосовується Аля зображення оАягу. Портретна практика В. Ганоцького окреслена межами реалістичної системи зображення

Висновки. В. А. Ганоцький $є$ носієм і продовжувачем традицій рєпінського напряму реа-
Аістичного портрета художньої школи Харкова. Майстер зАійснює взаємозв'язок сучасного мистецтва портрета 3 досягненнями майстрів попередніх поколінь, творчо переосмисливши їхню спадщину. Творчість учнів I. Ю. Рєпіна - Ф. А. Махявіна, М. І. Фєшина, фундаторів харківської художньої школи М. С. ФеАорова, С. М. Прохорова, О. А. Кокєия і їх посліАовників: Ю. В. Балановського, Г. О. Томенко, С. Ф. БесєАіна, Б. А. Колесника, О. В. Вяткіна, А. М. Константинопольського - вплинула на формування художньо-стилістичної мови В. $\Lambda$. Ганоцького. Цей фунАамент забезпечив високий рівень його професійної майстерності та надав можиивість втілення скмаАних художніх завдань.

У портретах 1980-х років Аомінує «об'ємнопластичний стиль». Основою композиційної структури $є$ темний силует на світлому тлі. МоАель зображується в інтер'єрі. Портрети цього періоду характеризуються маконізмом, виразністю силуету, визначеністю тонального рішення, стриманою кольоровою пацітрою.

Аля портретів 1990-х років характерне ускмаднення композиції шляхом введення мотиву натюрморту і пейзажу. «Живописний стиль» відзначається насиченістю кольорів, розчиненням абрису фігури у просторі зі збереженням головного акценту, утвореного світлом на обАиччі та кистях рук моделі. ПоєАнання академічної основи з експресією живописної манери зрілого періоду сприяє створенню емоційно виразних портретних образів. Висока ступінь схожості та віАтворений художником характер моделі наАікяють його композиції ознаками психологічного портрета. 


\section{\ітература}

1. Алпатов М. Композиция в живописи. Москва-АенинграА: Искусство, 1940. 128 с.: ил.

2. А^патов М. Очерки по истории портрета. Москва-АенинграА, 1937. 60 с.

3. Василь Ганоцький - на зламі століть та епох.: альбом / упор. О. Ганоцька. Харків: Майдан, 2011. 136 c.: is.

4. Вельфмин Г. Основные понятия истории искусств. Москва-АенинграА: ACADEMIA, 1930. $344 \mathrm{c}$.

5. Випnер Б. Введение в историческое изучение искусства. Москва: АСТ ПРЕСС КНИГА, 2004. $368 \mathrm{c.}$

6. Виппер Б. Проблема и развитие натюрморта. Санкт-Петербург: Азбука-классика, 2005. 384 с.: ил.

7. Власов В. Г. Новый энциклопедический словарь изобразительного искусства. В Х томах. Санкт-Петербург: Азбука-кмассика, 2008. Т. IX. 384 с.: ил. С. 463.

8. Пономаренко М. Інтерв'ю з художником М. А. Константинопольським. 17.06.15.

9. Пономаренко М. Інтерв'ю з художником В. А. Ганоцьким. 23.11.16.

10. Пономаренко М. Художньо-стилістичні особливості станкового портрету в живописі Харкова XX-XI ст.: Аис. ... канА. мистецтвознавства: 17.00.05. Харків: ХАААМ, 2016. 403 с.

11. Романовский В. Миры Василия Ганоцкого // Вечерний Харьков. 2001. 11 ноября.

12. Серебрякова Є. Роздуми в образах // Вечірній Харків. 1986. 22 березня.

13. Сарабьянов А. Стиль модерн. Москва: Искусство, 1989. 294 с.

14. Фаворский В. Аитературно-теоретическое наследие. Москва: Советский художник, 1988.

588 с.: ик.

15. Фаворский В. Об искусстве, о книге, о гравюре. Москва: Книга, 1986. 238 с.: ил.

\section{References}

1. Alpatov M. Kompozitsiya v zhivopisi. Moskva-Leningrad: Iskusstvo, 1940. 128 s.: il.

2. Alpatov M. Ocherki po istorii portreta. Moskva-Leningrad, 1937. $60 \mathrm{~s}$.

3. Vasy`l` Ganocz `ky`j - na zlami stolit` ta epox.: al bom / upor. O. Ganocz`ka. Xarkiv: Majdan, 2011. $136 \mathrm{s.:}$ il

4. Velflin G. Osnovnyie ponyatiya istorii iskusstv. Moskva-Leningrad: ACADEMIA, 1930. $344 \mathrm{~s}$.

5. Vipper B. Vvedenie v istoricheskoe izuchenie iskusstva. Moskva: AST PRESS KNIGA, 2004. $368 \mathrm{~s}$.

6. Vipper B. Problema i razvitie natyurmorta. Sankt-Peterburg: Azbuka-klassika, 2005. 384 s.: il.

7. Vlasov V. G. Novyiy entsiklopedicheskiy slovar izobrazitelnogo iskusstva. V H tomah. Sankt-

Peterburg: Azbuka-klassika, 2008. T. IH. 384 s.: il. S. 463.

8. Ponomarenko M. Interv yu z xudozhny`kom M. A. Konstanty`nopol `s ' ky`m. 17.06.15.

9. Ponomarenko M. Interv>yu z xudozhny`kom V. L. Ganocz’ky`m. 23.11.16.

10. Ponomarenko M. Xudozhn`o-sty listy`chni osobly`vosti stankovogo portretu v zhy`vopy`si Xarkova XX-XI st.: dy`s. ... kand. my`stecztvoznavstva: 17.00.05. Xarkiv: XDADM, 2016. 403 s.

11. Romanovskiy V. Miryi Vasiliya Ganotskogo // Vecherniy Harkov. 2001. 11 noyabrya.

12. Serebryakova Ye. Rozdumy`v obrazax // Vechirnij Xarkiv. 1986. 22 bereznya.

13. Sarabyanov D. Stil modern. Moskva: Iskusstvo, 1989. $294 \mathrm{s.}$

14. Favorskiy V. Literaturno-teoreticheskoe nasledie. Moskva: Sovetskiy hudozhnik, 1988. 588 s.: il.

15. Favorskiy V. Ob iskusstve, o knige, o gravyure. Moskva: Kniga, 1986. 238 s.: il. 


\section{Пономаренко М. В. Художественно-стихистические особенности портретных произведений Васимия Аеонтьевича Ганоцкого}

Аннотация. Рассмотрены произведения портретного жанра преАставителя репинского направления харьковской школы живописи - В. А. Ганоцкого. Творчество мастера анализируется в контексте становцения и развития портретной живописи Харькова. Выявлена роль художника в сохранении традиций в художественно-стилистической системе украинского станкового портрета последней трети XX-XXI веков. Проанализированы художественно-стилистические особенности произведений портретного жанра: композиционная, колористическая, светотональная структура, техника исполнения.

В результате проведенного художественно-стилистического анализа сделаны выводы, о том, что в портретных образах 1980х годов доминирует «объемно-пластический стиль» с присущим ему ясным соотношением персонажа и пространства. Портреты этого периода характеризуются каконизмом, выразительностью сикуэта, определенностью тонального решения, сдержанной цветной палитрой.

Раскрыто, что на формирование искусства зрелого периода мастера 1990-х годов повцияла живопись барокко, романтизма и модерна. Стилистику портретов этого периода мы определяем как «живописную» (согласно терминологии Г. Вельфлина). Выяснено, что главная особенность картин художника заключается в напряженном контрасте светотеневой палитры. САеланы выводы, что в результате усложнения композиционного строя портрета путем введения мотива пейзажа и натюрморта изображение индивиАуальной Аичности становится портретом-картиной.

Ключевые слова: жанр портрета, харьковская художественная школа, живопись В. А. Ганоцкого.

\section{Ponomarenko $M . V$. Artistic and stylistic features of portraiture of Vasily Leontyevich Ganotsky}

Abstract. The works of the portrait genre of the representative of the Repin's direction of the Kharkiv school of painting - V. L. Ganotsky are studied. Creativity of the master is analyzed in the context of the formation and development of portrait painting in Kharkiv. The role of the artist in preserving traditions in the artistic and stylistic system of the Ukrainian easel portrait of the last third of the XX-XXI centuries is revealed. The artistic and stylistic features of the works of the portrait genre are analyzed: compositional, coloristic, light-tonal structure, technique of execution.

As a result of the artistic and stylistic analysis, it was concluded that the "volume-plastic style" dominates the portrait images of the 1980 s, with its inherent clear correlation between character and space. Portraits of this period are characterized by conciseness, expressiveness of silhouette, certainty of tonal solution, restrained by color palette.

It is revealed that the art of Baroque, Romanticism and Art Nouveau influenced the formation of art by the masters of the mature period of the 1990s. We define the style of portraits of this period as "pictorial" (according to the terminology of G. Wölflin). It was found that the main feature of the artist's paintings lies in the intense contrast of the light-and-dark palette. It is concluded that as a result of the complexity of the compositional structure of the portrait by the introduction of the motive of the landscape and still life, the image of an individual personality becomes a portrait-picture.

Keywords: portrait genre, Kharkiv art school, painting by V. L. Ganotsky. 